Web of Science $^{\mathrm{Tm}} \quad$ Search Marked List History Alerts Sign In $\vee \quad$ Register

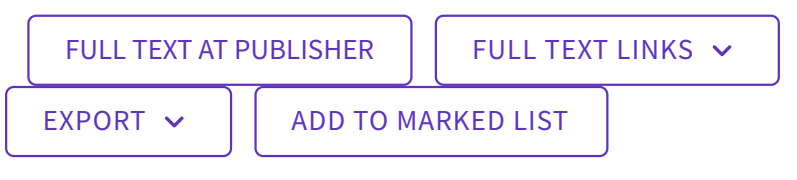

$<$ of $1>$

\section{Households' acceptance of affordable Islamic public-private housing co-operative model (IPHCM) in Malaysia}

By: Razak, DA (Abdul Razak, Dzuljastri) ${ }^{1}$; Bilal, M (Bilal, Muhammad) ${ }^{2}$; Amin, $\mathrm{H}$ (Amin, Hanudin) ${ }^{3}$

INTERNATIONAL JOURNAL OF ISLAMIC AND MIDDLE EASTERN FINANCE AND MANAGEMENT

Volume: 14 Issue: 1 Page: 34-56

DOI: $10.1108 /$ IMEFM-08-2019-0325

Published: FEB 62021

Early Access: NOV 2020

Document Type: Article

\section{Abstract}

Purpose

The purpose of this study is to examine the determinants influencing low- and middle-income households in accepting the Islamic public-private housing co-operative model (IPHCM) as an alternative to contemporary affordable public housing models in Malaysia.

Design/methodology/approach

Using self-administrated questionnaires, data are collected from low- and middle-income households dwelling in Programme Perumahan Rakyat projects in Kuala Lumpur and the state of Selangor. The study used the theory of planned behaviour (TPB) and used the partial least squares technique to examine the proposed hypothesised relationships.

Findings

The findings of this study suggest that subjective norm and perceived consumer religiosity is the most influential determinants affecting the behavioural intention of low- and middle-income households in accepting the IPHCM model. Attitude had a significantly positive relationship with households' behavioural intentions towards accepting the IPHCM model.

Practical implications

The findings of this study can serve as a guideline for policymakers to understand the behavioural intention of lowand middle-income households in accepting newly developed models in affordable public housing space.

\section{Citation Network}

In Web of Science Core Collection

0

Citations

Create citation alert

Cited References

\section{9}

View Related Records

\section{Use in Web of Science}

Web of Science Usage Count

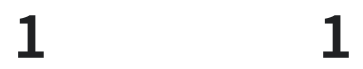

Last 180 Days $\quad$ Since 2013

Learn more

This record is from:

Web of Science Core Collection

Social Sciences Citation Index 
Originality/value

Behavioural aspects regarding the acceptance of affordable public housing models in Malaysia have yet to be profoundly explored in the literature. This study has extended the TPB by incorporating perceived consumer religiosity, in the affordable public housing domain, to analyse its effects on households' acceptance of the IPHCM model.

\section{Keywords}

Author Keywords: Affordable housing; Perceived consumer religiosity; Attitude; Behavioural intention; Public housing; Islamic public-private housing co-operative model (IPHCM); Islamic home financing

Keywords Plus: STRUCTURAL EQUATION MODELS; CHOOSE HALAL PRODUCTS; PLANNED BEHAVIOR; PREDICTING INTENTION; NORMATIVE BELIEFS; RELIGIOSITY; CONSUMPTION; ADOPTION; HEALTH; DETERMINANTS

\section{Author Information}

$\begin{array}{lll}\text { Corresponding } & \text { : Bilal, } & \text { (corresponding } \\ \text { Address } & \text { Muhammad } & \begin{array}{l}\text { author) } \\ \text { Auther }\end{array}\end{array}$

Gen Council Islamic Banks \& Financial Inst CIBAFI, Manama, Bahrain

\section{Author Addresses:}

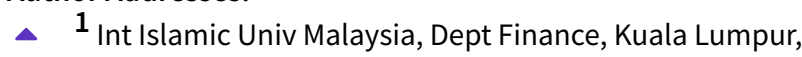
Malaysia

\section{Affiliation}

International Islamic University Malaysia

2 Gen Council Islamic Banks \& Financial Inst CIBAFI, Manama, Bahrain

- 3 Univ Malaysia Sabah, Labuan Fac Int Finance, Kota Kinabalu, Sabah, Malaysia

Affiliation

Universiti Malaysia Sabah

E-mail Addresses: dzuljastri2000@yahoo.com; mbilalafzal@hotmail.com; hanudin@ums.edu.my

Categories/Classification

Research Areas: Business \& Economics

+ See more data fields

\section{Journal information}

International Journal Of Islamic And Middle Eastern Finance And Management

ISSN: $1753-8394$

eISSN: $1753-8408$

Current Publisher: EMERALD GROUP PUBLISHING LTD, HOWARD HOUSE, WAGON LANE, BINGLEY BD16 IWA, W YORKSHIRE, ENGLAND

Journal Impact Factor: Journal Citation Report ${ }^{\mathrm{TM}}$ Research Areas: Business \& Economics Web of Science Categories: Business, Finance; Management 


\section{Cited References}

Showing 30 of 129

VIEW AS SET OF RESULTS

(from Web of Science Core Collection) 

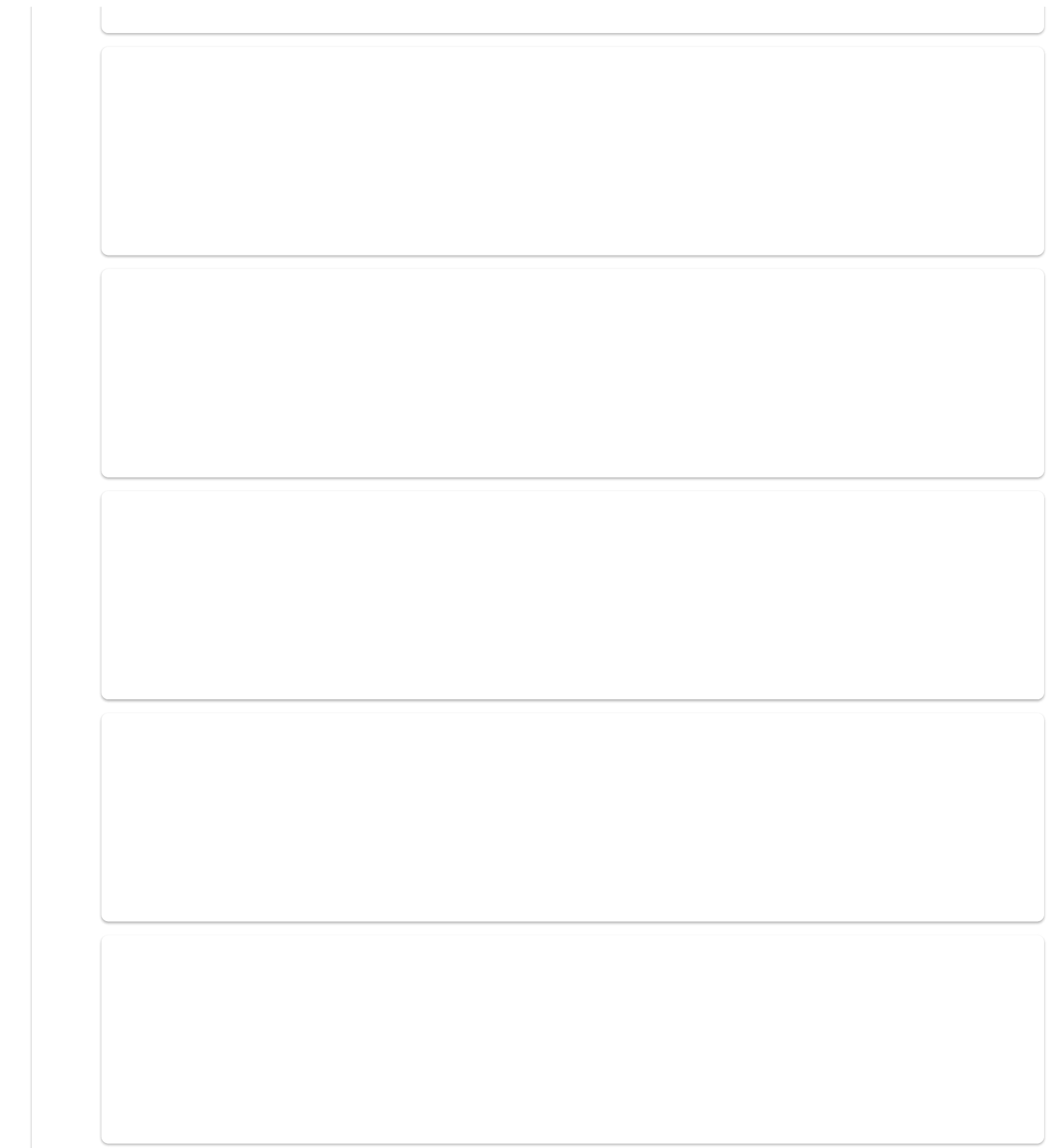

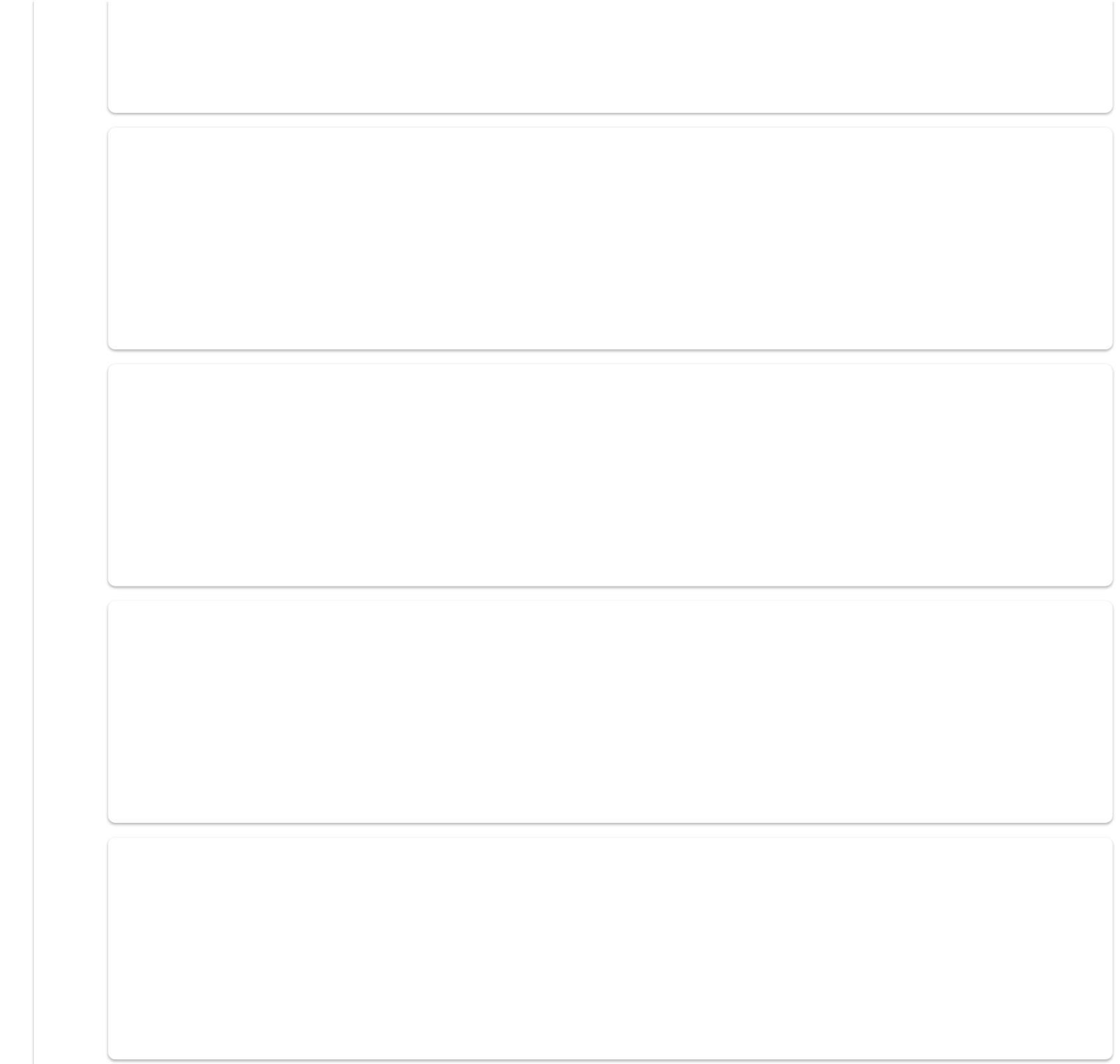

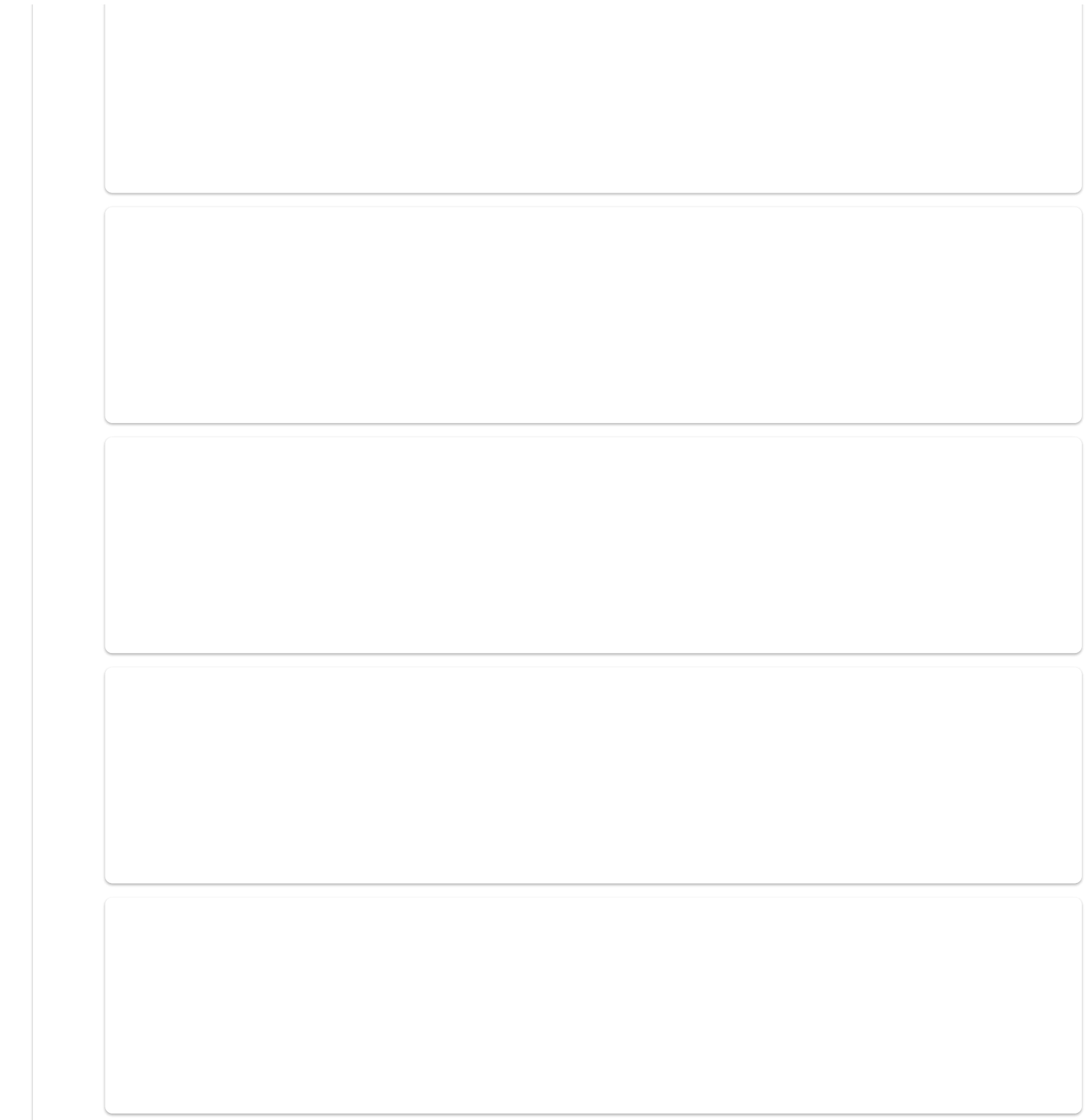


$\begin{array}{llll}\text { (c) 2021 Clarivate } & \text { Data Correction } & \text { Copyright Notice } & \text { Follow Us } \\ \text { Training Portal } & \text { Privacy Statement } & \text { Cookie Policy } & \mathbf{f} \\ \text { Product Support } & \text { Newsletter } & \text { Terms of Use } & \end{array}$

